\title{
Analysis of the quality characteristics of Kochujang prepared using pastes from different peach varieties
}

\author{
Kyung-Mi Jung $^{1 *}$, Yong-Jin Jeong ${ }^{2}$ \\ ${ }^{1}$ Cheongdo Peach Research Institute, GyeongSangBuk-Do Agricultural Technology Administration, Cheongdo 38315, Korea \\ ${ }^{2}$ Department of Food Science and Technology, Keimyung University, Daegu 42601, Korea
}

\section{복숭아 품종별 페이스트를 이용한 고추장의 품질 특성}

\author{
정경미 ${ }^{1 *} \cdot$ 정용진 $^{2}$ \\ ${ }^{1}$ 경상북도 농업기술원 청도복숭아연구소, ${ }^{2}$ 계명대학교 식품보건학부
}

\begin{abstract}
In this study, we aimed to increase the utilization of non-commercializable peach fruits collected during harvesting and distribution and to promote the transition of a high value-added industry. After producing pastes from the flesh of different peach varieties, we used these pastes as ingredients in the production of Kochujang. We then performed a comparative analysis on the quality characteristics of the peach-added Kochujang and commercially available Kochujang products. Peach-added Kochujang exhibited a lower pH and reduced sugar, salinity, reducing sugar, ash, and calorie content than those of commercially available Kochujang products. However, the Kochujang had slightly higher $\mathrm{pH}$ and moisture content than commercially available products due to high organic acid and moisture contents of peach flesh. In terms of content of inorganic elements, commercial Kochujang products exhibited higher sodium and magnesium content, whereas peach-added Kochujang had higher potassium content. In particular, the lower sodium and higher potassium content of peach-added Kochujang indicates that this product could be used as a functional food to prevent various diseases caused by excessive sodium intake among Koreans. After comparing the products in terms of phenol and flavonoid content, we concluded that ethanol extracts of peach-added Kochujang showed higher phenol content than those of the commercially available Kochujang products. In contrast, the distilled water extracts of peach Kochujang showed higher DPPH free radical scavenging activity than that of commercially available Kochujang products.
\end{abstract}

Key words : Kochujang, Prunus persica, peach paste, total phenol

\section{서 론}

우리나라의 전통 음식은 오랜 역사를 거쳐 기후와 풍토 에 맞게 진화하고 발달해 왔다. 특히, 전통 발효식품 중 고추장, 된장 간장은 대표적인 장류 발효식품으로서 삼국 시대부터 기인하여 오랜 역사를 가지고 있다. 그 중 고추장

*Corresponding author. E-mail : kmgod@korea.kr Phone : 82-54-373-5486, Fax : 82-54-373-5487

Received 6 December 2017; Revised 15 January 2018; Accepted 24 January 2018.

Copyright (c) The Korean Society of Food Preservation. All rights reserved.
은 16 세기 말에서 17 세기 초에 제조하기 시작한 것으로 추정하고 있으며, 현재와 비슷한 제조 방법은 18 세기에 정 립된 것으로 기록되어 있다(1). 고추장은 고춧가루, 메주, 전분 및 소금을 주원료로 하는 전통발효식품이며, 단맛, 매운맛, 짠맛, 구수함이 어우러져 있는 독특하고 조화로운 영양식품으로 오랫동안 각광받아왔다(2). 또한, 고추장의 주재료인 고추에 함유되어 있는 캡사이신은 항암, 항산화 및 지방 분해 활성 등 많은 생리 활성물질로 인정되고 있다 (3).

최근 한식세계화와 맞물려 전통 고추장에 국한되어 있는 제조법에서 벗어나 새로운 소재를 활용한 고추장의 연구가 활발히 진행되고 있다. 이에 대한 선행 연구로는 단감 분말 
(4), 대추(5), 더덕 분말(6), 매실 농축액(7), 밤(8) 등을 첨가 한 고추장의 연구 개발이 있으며, 이와 같은 연구 결과에 따라 고추장을 제조할 때 새로운 소재의 활용은 맛의 다양 성, 기능성의 증진 및 품질 향상에 도움을 줄 수 있다고 보고되고 있다.

복숭아(Prunus persica L. Batsch)는 장미과(Rosaceae), 자 두속(Prunus), 복숭아과속(Amygdalus)에 속하는 과수로 우 리나라의 대표적인 여름 과일이다(9). 주성분은 수분과 당 분으로 이루어져 있으며 유기산, 에스테르, 펙틴 등이 풍부 하고, aspartic acid, serine 등의 아미노산을 많이 함유하고 있다(10). 복숭아는 크게 과육의 색에 따라 황도계와 백도계 로 나뉘며, 털의 유무에 따라 유모종과 무모종으로 나뉜다. 또한, 백도계의 색소는 주로 cyanidine 배당체로 이루어져 있으며, 황도계는 $\beta$-carotene, cryptoxanthin 등의 carotenoid 계 색소로 이루어져 있어 노화억제, 항산화 작용, 항암 작용 등 다양한 기능적 활성을 가지고 있다고 보고되었다(11). 국내의 복숭아 소비는 주로 6-9월에 집중되어 있고 대부분 생과로 소비되고 있다. 복숭아는 다른 과일에 비하여 호흡 량이 많아 온도가 높을수록 호흡작용에 의한 과실 내 양분 의 소모가 많으며, 이러한 이유로 유통 중 신선도가 급격히 떨어지거나 과육이 쉽게 물러지므로 $10-30 \%$ 에 해당하는 많은 양이 폐기되는 실정이다(12). 따라서 수확기에 일시 출하가 불가피 하여 저장성이 낮은 복숭아의 가격 경쟁력을 약화시켜 농가 소득에 큰 어려움을 주는 실정이다(13). 이에 따라 복숭아의 저장성을 높이기 위한 선행 연구(14), 통조 림, 잼, 주스 등의 가공품을 통해서 고부가가치로의 전환을 위하여 노력을 하고 있으나, 다른 과일에 비해 가공품의 다양성이 부족하다는 한계점과 다품종 소량 생산이라는 복숭아의 특징상, 가공품으로 전환할 때 단일 품종만으로 는 규격화된 생산이 어려운 실정이다.

본 연구에서는 폐기되고 있는 저급 복숭아를 활용하는 방안으로 과육을 페이스트 형태로 제조하여 고추장을 담금 하고 품질 특성을 조사하여 상품화를 위한 기초 자료로 활용하고자 한다.

\section{재료 및 방법}

\section{실험 재료}

경상북도 농업기술원 청도복숭아연구소의 포장에서 2016년 수확한 품종별 복숭아(가납암백도, 천홍, 장호원황 도)를 흐르는 물에 세척 후 상온에서 10시간 건조시켜 물기 를 제거하고, 씨를 분리한 과육을 재료로 사용하였다. 각각 의 복숭아 품종별 과육을 파쇄하고, $90^{\circ} \mathrm{C}$ 에서 2 시간 동안 가열, 농축하여 얻은 $24{ }^{\circ} \mathrm{Brix}$ 의 페이스트를 고추장 제조의 재료로 각각 사용하였다.
복숭아 고추장의 담금

복숭아 품종별 페이스트를 이용한 고추장의 품질 특성을 조사하기 위한 고추장 조성비는 Table 1과 같다. 겉보리를 원료로 한 엿기름 가루를 미지근한 물 $\left(65^{\circ} \mathrm{C}\right)$ 에 골고루 풀고 1 시간 동안 불려놓았다. 불린 엿기름을 주물러준 뒤 채에 거르는 과정을 3 회 반복하고, 곱게 파쇄한 찹쌀가루와 혼합 하여 $60^{\circ} \mathrm{C}$ 의 약한 불에 재가열하여 3 시간 동안 당화시켰다. 당화시킨 엿기름액에 균일하게 파쇄한 고춧가루와 천일염, 조청, 메줏가루, 주정 및 품종별 복숭아 페이스트를 Table 1 에 나타낸 배합비로 혼합하여, $4 \mathrm{~kg}$ 씩을 각각 용기에 병입 하였다. 병입한 후 $20-30^{\circ} \mathrm{C}$ 의 실내온도에서 1 개월간 숙성시 킨 후 분석시료로 사용하였다. 각 실험군 및 대조군에 해당 하는 고추장은 2-1,000배 희석하여 품질특성을 측정하였으 며, 항산화능을 측정하기 위하여 각 복숭아 품종별 고추장 을 증류수(distilled water) 및 $100 \%$ ethanol에 $1: 5(\mathrm{w} / \mathrm{v})$ 의 비 로 $50^{\circ} \mathrm{C}, 150 \mathrm{rpm}$ 하에서 24시간 추출하여 동결건조(Freezer Dryer, Operon Eng Co., Seoul, Korea)한 후, 농도 $(50 \mathrm{mg} / \mathrm{mL}$, $100 \mathrm{mg} / \mathrm{mL}$ )를 설정하여 실험에 사용하였다. 각각의 복숭아 품종별 페이스트로 담금한 KHK(Kanoiwa Hakuto(가납암 백도) Kochujang), CHK(Cheonhong(천홍) Kochujang), CWK(Changhowon Hwangdo(장호원황도) Kochujang) 및 MK(Mixed(KHG:CHG:CWG, 1:1:1) Kochujang) 고추장과 품 질 비교를 위한 대조구로 CK(commercial Kochujang(순창 고추장, Daesang, Seoul, Korea))의 품질특성을 각각 분석하 였다.

Table 1. The mixing ratio for preparation of Kochujang added with peach paste

\begin{tabular}{cc}
\hline Raw materials & $\%(\mathrm{w} / \mathrm{w})$ \\
\hline Red pepper powder & 15 \\
Meju powder & 3 \\
Salt & 6 \\
Glutinous rice & 10 \\
Grain syrup & 30 \\
Soju & 5 \\
Peach paste & 31 \\
\hline Total & 100 \\
\hline
\end{tabular}

$\mathrm{pH}$, 당도, 염도 및 총산도 측정

복숭아 품종별 고추장 시료를 증류수에 10 배 희석하여 $\mathrm{pH}$, 당도, 염도 및 총산도를 측정하였다. $\mathrm{pH}$ 는 $\mathrm{pH}$ meter(Orion star A221, Thermo Electron Co., MA, USA)를 사용하여 측정하였고, 당도는 당도계(PAL-2, Atago Co., Ltd., Tokyo, Japan), 염도는 염도계(PAL-SALT, Atago Co.) 를 사용하여 측정하였다. 총산도는 10 배 희석된 고추장 시 료를 원심분리 후 상등액을 취하여 여과지(Whatman No.2, Maidstone, England)에 거른 후, 여과액 $20 \mathrm{~mL}$ 을 취하여 
$1 \%$ phenolphthalein(Daejung, Seoul, Korea)용액을 2-3방울 첨가하고, $0.1 \mathrm{~N} \mathrm{NaOH}$ 를 이용하여 여과액이 분홍색을 띨 때까지 적정하여 소비된 $0.1 \mathrm{~N} \mathrm{NaOH}$ 의 양으로 총산도를 도출하였다. 유기산의 당량은 구연산으로 환산하였다(15).

\section{수분, 회분, 열량 및 환원당}

고추장 품종별 시료 $2 \mathrm{~g}$ 을 취하여 수분, 회분 및 열량을 측정하였다. 시료의 수분은 마이크로웨이브 수분측정기 (LMA200PM, Satorius, Göttingen, Germany)를 이용하여 측 정하였고, 회분 함량은 직접회화법을 이용하여 측정하였 다. 열량은 단백질, 지방, 탄수화물 등 영양성분 측정 결과를 토대로 환산하여 결과값을 도출하였다. 환원당은 dinitrosalicylic $\operatorname{acid}(\mathrm{DNS})$ 법으로 측정하였다. 품종별 고추장 시료를 1,000 배 희석하여 $\mathrm{DNS}$ 시약 $1 \mathrm{~mL}$ 을 첨가한 후, 끓는 물에 5 분간 반응시키고 반응을 멈추기 위하여 $20^{\circ} \mathrm{C}$ 에서 방냉하였다. 반응이 끝난 후, test tube에 증류수 $3 \mathrm{~mL}$ 을 넣어 희석하여 $546 \mathrm{~nm}$ 에서 흡광도를 측정하였다. 표준용액은 glucose를 이용하여 측정 후 검량선을 작성하여 계산하였다(16).

\section{유리당}

고추장 품종별 시료 $2.5 \mathrm{~g}$ 을 증류수에 첨가하여 최종 $30 \mathrm{~g}$ 이 되게 희석하여 원심분리관에 취하였다. 이를 $85^{\circ} \mathrm{C}$ 에 서 25분간 가온하고 실온으로 냉각한 뒤, $3,000 \mathrm{rpm}$ 에서 10 분간 원심분리(Heraeus Megafuge 16R, Thermo Scientific, Waltham, MA, USA)하였다. 원심분리하여 얻은 상징액을 $0.45 \mu \mathrm{m}$ membrane filter(Advantec MFS, Inc., Dubulin, CA, USA)로 여과하여 HPLC(Coulter System Gold, Beckman, Brea, CA, USA / Prominence modular HPLC, Shimadzu, Kyoto, Japan)로 분석하였다. 분석 column은 Carbohydrate Analysis(3.9 $\times 300 \mathrm{~mm}, 35^{\circ} \mathrm{C}$, Waters Co., Milford, MA, USA) 를 사용하여, Mobile phase는 $80 \%$ acetonitrile, flow rate 1.0 $\mathrm{mL} / \mathrm{min}$, injection volume $20 \mu \mathrm{L}$, detector는 refractive index detector(RID-10A, Shimadzu, Kyoto, Japan)를 사용하였다. 표준물질은 fructose, glucose, sucrose 및 maltose(Sigmaaldrich, St. Louis, MO, USA)를 사용하여 시료와 동일한 조건에서 분석하여 머무름 시간을 비교해 확인하였으며, 검량곡선으로부터 그 함량을 산출하였다.

\section{영양성분 및 무기원소}

단백질, 지방, 탄수화물 및 콜레스테롤 함량은 고추장 품종별 시료 $2 \mathrm{~g}$ 을 취하여 측정하였다. 분석 방법은 식품공 전(17)을 참고하여 동일한 방법으로 실행하였다. 무기원소 는 고추장 품종별 시료를 $1 \mathrm{~g}$ 씩 취하여 증류수 $20 \mathrm{~mL}$ 에 희석한 후, $70 \%$ 질산 $20 \mathrm{~mL}$ 을 첨가하여 상온에서 적당히 방치하였다. 원자 흡수 분광계(iCE3000 Series AA Spectrometer, Thermo Scientific)를 이용하여 무기원소 함량 $(\mathrm{K}, \mathrm{Ca}, \mathrm{Mg}$, $\mathrm{Na}$ )을 측정하였다. 분석 방법은 $\mathrm{AOAC}$ 의 표준분석법(18)
을 참고하여 동일한 방법으로 실행하였다.

총 페놀 및 플라보노이드 함량

총 페놀 함량은 Folin-Denis 방법(19)을 변형하여 측정하 였다. Microplate reader(BMG Labtech, Spectrostar Nano, Ortenberg, Germany)로 $595 \mathrm{~nm}$ 에서 흡광도를 측정하였다. 표준물질로는 gallic acid를 사용하였으며, 시료와 동일한 방법으로 분석하여 검량선을 작성한 후 총 페놀 함량을 산출하였다.

총 플라보노이드 함량은 Zhishen 등(20)의 방법을 사용하 여 측정하였다. 표준물질로는 catechin을 사용하였으며, 시 료와 동일한 방법으로 분석하여 검량선을 작성한 후 총 플라보노이드 함량을 산출하였다.

\section{$\mathrm{DPPH}, \mathrm{ABTS}$ 활성}

2,2-Diphenyl-1-picrylhydrazyl(DPPH) 라디칼 소거능 측 정은 Blois의 방법(21)을 변형하여 측정하였다.

$\mathrm{ABTS}$ 라디칼 소거능 측정은 $\mathrm{Re}$ 의 방법(22)을 변형하여 측정하였다. $7 \mathrm{mM} \mathrm{ABTS}[2,2$ '-azino-bis(3-ethylbenzothiazoline6-sulphonic acid)]와 $2.45 \mathrm{mM}$ potassium persulfate를 최종 농도로 혼합하여 암소에서 24시간 동안 방치한 후, $595 \mathrm{~nm}$ 에서 흡광도 값이 $0.700 \pm 0.002$ 가 되도록 phosphate buffer saline(PBS, $\mathrm{pH}$ 7.4)로 조정하여 제조한 후, 실험에 사용하였 다.

\section{통계 분석}

본 연구에 실행된 실험은 3회 반복 수행하여 평균과 표준 편차로 나타내었고, 평균값의 비교는 SAS 프로그램을 이용 하여 분산분석(ANOVA) 및 Duncan's multiple range test을 통해 유의수준 $5 \%(\mathrm{p}<0.05)$ 에서 수행되었다.

\section{결과 및 고찰}

\section{$\mathrm{pH}$, 당도, 염도 및 총 산도}

품종별 복숭아 고추장의 $\mathrm{pH}$, 당도, 염도 및 총 산도를 측정한 결과는 Table 2 와 같다. 복숭아 고추장의 $\mathrm{pH}$ 의 경우 대조군인 $\mathrm{CK}$ 군이 $4.99 \pm 0.01$ 로 가장 높은 반면에 $\mathrm{CHK}$ 군이 $4.34 \pm 0.05$ 로 가장 낮았다. Lee와 Youn(23)은 백도 계통인 유명과 천도 계통인 천홍의 품질특성 연구에서 생과인 상태 의 천홍은 $\mathrm{pH} 3.41$, 유명은 $\mathrm{pH} 4.17$ 이라는 결과를 얻었고, 이는 천도 계통의 복숭아가 다른 계통의 복숭아에 비해 낮은 $\mathrm{pH}$ 를 가지는 경향이 있다는 것을 보여준다. 이에 따라 천도 계통인 천홍의 페이스트을 이용하여 제조한 고추장인 $\mathrm{CHK}$ 군의 $\mathrm{pH}$ 가 가장 낮은 결과를 나타낸 것으로 사료되며, 그 외 다른 품종에서는 유의적인 차이를 보이지 않았다. $\mathrm{CK}, \mathrm{KHK}, \mathrm{CHK}, \mathrm{CWK}, \mathrm{MK}$ 군의 당도는 $60.00 \pm 0.00 \%$, 
$53.00 \pm 1.00 \%, 50.67 \pm 1.53 \%$ 및 $51.67 \pm 0.58 \%$ 로 실험군에서 유의적인 차이를 보였고(p<0.05), 대조군에 비해 당도가 낮 은 경향을 보였다. 이는 고추장 제조 시 복숭아 페이스트의 첨가 유무와 숙성 중의 변화에 따른 결과라고 사료된다. 염도는 당도와 같이 대조군에 비해 실험군에서 낮은 결과를 보였는데, 이는 고추장의 제조 과정 중 천일염의 첨가 비율 에 따른 결과라고 볼 수 있다. 총 산도의 경우, $\mathrm{CK}$ 군에서 $0.86 \pm 0.04 \%$ 의 산도를 보였으며, $\mathrm{KHK}, \mathrm{CHK}, \mathrm{CWK}, \mathrm{MK}$ 군 은 각각 $1.02 \pm 0.03 \%, 0.93 \pm 0.03 \%, 1.24 \pm 0.05 \%$ 및 $1.10 \pm$ $0.04 \%$ 의 산도를 보였다. 대조구에 비해 실험군에서의 총 산도가 높은 경향을 보였고, 이는 Lee 등(10)의 연구 결과에 따라 복숭아의 풍부한 유기산 함량으로 인하여 높은 산도를 나타내는 것으로 사료된다.

Table 2. $\mathrm{pH}$, sugar, salinity, and total titratable acidity content of Kochujang added with peach paste

\begin{tabular}{ccccc}
\hline Cultivar $^{1)}$ & $\mathrm{pH}$ & $\begin{array}{c}\text { Sugar } \\
(\%)\end{array}$ & $\begin{array}{c}\text { Salinity } \\
(\%)\end{array}$ & $\begin{array}{c}\text { Total titratable acidity } \\
(\%)\end{array}$ \\
\hline KHK & $4.61 \pm 0.02^{2 \mathrm{bb3})}$ & $53.00 \pm 1.00^{\mathrm{c}}$ & $5.60 \pm 1.17^{\mathrm{bc}}$ & $1.02 \pm 0.03^{\mathrm{c}}$ \\
$\mathrm{CHK}$ & $4.34 \pm 0.05^{\mathrm{c}}$ & $50.67 \pm 1.53^{\mathrm{d}}$ & $5.70 \pm 0.10^{\mathrm{bc}}$ & $0.93 \pm 0.03^{\mathrm{d}}$ \\
$\mathrm{CWK}$ & $4.60 \pm 0.06^{\mathrm{b}}$ & $55.33 \pm 1.53^{\mathrm{b}}$ & $5.50 \pm 0.17^{\mathrm{c}}$ & $1.24 \pm 0.05^{\mathrm{a}}$ \\
MK & $4.67 \pm 0.16^{\mathrm{b}}$ & $51.67 \pm 0.58^{\mathrm{cd}}$ & $5.77 \pm 0.06^{\mathrm{b}}$ & $1.10 \pm 0.04^{\mathrm{b}}$ \\
$\mathrm{CK}$ & $4.99 \pm 0.01^{\mathrm{a}}$ & $60.00 \pm 0.00^{\mathrm{a}}$ & $6.53 \pm 0.06^{\mathrm{a}}$ & $0.86 \pm 0.04^{\mathrm{e}}$ \\
\hline
\end{tabular}

${ }^{1}$ KHK, Kanoiwa Hakuto Kochujang, CHK, Cheonhong Kochujang, CWK, Changhowon Hwangdo Kochujang, MK, mixed Kochujang, CK, commercial Kochujang.

${ }^{2}$ )Values are means \pm SD of triplicate determinations.

${ }^{3}$ Different superscripts within a column (a-e) indicate significant differences $(\mathrm{p}<0.05)$.

\section{수분, 회분, 열량 및 환원당의 함량}

복숭아 품종별 고추장의 수분, 회분, 열량 및 환원당의 결과는 Table 3에 나타내었다. 전체적으로 수분은 대조군에 비하여 실험군에서 높은 결과를 얻을 수 있었고, 실험군내 의 유의적인 차이는 없었다. 반면, 회분의 함량은 $7.53 \pm$ $0.00 \%$ 의 $\mathrm{CK}$ 군에 비해 $\mathrm{KHK}, \mathrm{CHK}, \mathrm{CWK}, \mathrm{MK}$ 군은 $7.29 \pm 0.03 \%, 7.14 \pm 0.02 \%, 7.13 \pm 0.06 \%$ 및 $7.02 \pm 0.05 \%$ 로 낮 은 결과를 보였다. 열량 또한 $\mathrm{CK}$ 군은 $240.50 \pm 0.71 \mathrm{kcal} / 100$ $\mathrm{g}$ 에 비해 $\mathrm{KHK}, \mathrm{CHK}, \mathrm{CWK}, \mathrm{MK}$ 군은 $224.50 \pm 0.71 \mathrm{kcal} / 100$ $\mathrm{g}, \quad 225.50 \pm 2.12 \mathrm{kcal} / 100 \mathrm{~g}, 225.00 \pm 0.00 \mathrm{kcal} / 100 \mathrm{~g}$, $239.50 \pm 0.71 \mathrm{kcal} / 100 \mathrm{~g}$ 으로 낮은 결과를 보였다. 이는 Youn 등(24)의 홍삼과 산야초 발효액을 첨가한 고추장의 연구와 유사한 결과를 나타내었다. 환원당은 고추장의 원료인 전 분이 amylase에 의해 분해되어 생성되는 성분으로 고추장 의 단맛에 직접적으로 관여하는 물질이다(25). 실험 결과 $\mathrm{CK}$ 군은 $848.84 \pm 8.99 \mathrm{mg} / \mathrm{mL}$ 의 농도를 보였고 $\mathrm{KHK}, \mathrm{CHK}$, CWK, MK군은 $829.81 \pm 7.60 \mathrm{mg} / \mathrm{mL}, 825.05 \pm 3.75 \mathrm{mg} / \mathrm{mL}$, $827.21 \pm 10.88 \mathrm{mg} / \mathrm{mL}, 819.43 \pm 1.98 \mathrm{mg} / \mathrm{mL}$ 로 나타나 대조구 인 시판고추장에 비해 복숭아를 첨가한 고추장에서 환원당 의 함량이 낮은 경향을 보였다. 이는 Table 2에서 당도의
결과와 유사한 경향을 보였고, 환원당 함량이 당도에 영향 을 미친다고 사료된다.

Table 3. Moisture, ash, calorie, and reducing sugar content of Kochujang added with peach paste

\begin{tabular}{ccccc}
\hline Cultivar $^{\mathrm{l})}$ & $\begin{array}{c}\text { Moisture } \\
(\%)\end{array}$ & $\begin{array}{c}\text { Ash } \\
(\%)\end{array}$ & $\begin{array}{c}\text { Calorie } \\
(\mathrm{kcal} / 100 \mathrm{~g})\end{array}$ & $\begin{array}{c}\text { Reducing sugar } \\
(\mathrm{mg} / \mathrm{mL})\end{array}$ \\
\hline KHK & $\left.37.83 \pm 0.14^{2 \mathrm{a} 3)}\right)$ & $7.29 \pm 0.03^{\mathrm{b}}$ & $224.50 \pm 0.71^{\mathrm{c}}$ & $829.81 \pm 7.60^{\mathrm{b}}$ \\
CHK & $37.83 \pm 0.38^{\mathrm{a}}$ & $7.14 \pm 0.02^{\mathrm{c}}$ & $225.50 \pm 2.12^{\mathrm{c}}$ & $825.05 \pm 3.75^{\mathrm{b}}$ \\
CWK & $37.78 \pm 0.09^{\mathrm{a}}$ & $7.13 \pm 0.06^{\mathrm{c}}$ & $225.00 \pm 0.00^{\mathrm{c}}$ & $827.21 \pm 10.88^{\mathrm{b}}$ \\
MK & $36.09 \pm 0.12^{\mathrm{b}}$ & $7.02 \pm 0.05^{\mathrm{d}}$ & $239.50 \pm 0.71^{\mathrm{b}}$ & $819.43 \pm 1.98^{\mathrm{b}}$ \\
CK & $33.41 \pm 0.18^{\mathrm{c}}$ & $7.53 \pm 0.00^{\mathrm{a}}$ & $240.50 \pm 0.71^{\mathrm{a}}$ & $848.84 \pm 8.99^{\mathrm{a}}$ \\
\hline
\end{tabular}

${ }^{1}$ KHK, Kanoiwa Hakuto Kochujang, CHK, Cheonhong Kochujang, CWK, Changhowon 2) Hwangdo Kochujang, MK, mixed Kochujang, CK, commercial Kochujang.

${ }^{2)}$ Values are means \pm SD of triplicate determinations.

${ }^{3}$ Different superscripts within a column $(a-d)$ indicate significant differences $(p<0.05)$.

\section{유리당 함량}

복숭아 품종별 고추장의 유리당 함량은 Table 4에 나타내 었다. 복숭아는 유과기에 잎에서 sorbitol의 형태로 전류되 어 과실의 대부분은 fructose와 glucose 형태로 저장된다. 이어 성숙기에 이르러 fructose와 glucose의 함량은 줄어드 는 반면에 sucrose의 함량이 총 유리당의 $70 \%$ 이상을 차지 하게 된다(26). 유리당의 조성 및 함량 비율은 유기산과 함께 복숭아의 품질과 맛을 좌우하는 요소이며(27), 복숭아 가공품의 품질 및 맛을 좌우하는 요소이기도 하다. 복숭아 페이스트를 첨가한 고추장의 유리당 함량을 살펴보면, fructose는 CK군에서 $0.89 \pm 0.01 \mathrm{~g} / 100 \mathrm{~g}$ 의 함량을 보였고 $\mathrm{KHK}, \mathrm{CHK}, \mathrm{CWK}, \mathrm{MK}$ 군은 $4.04 \pm 0.37 \mathrm{~g} / 100 \mathrm{~g}, 3.79 \pm 0.07$ $\mathrm{g} / 100 \mathrm{~g}, 4.55 \pm 0.05 \mathrm{~g} / 100 \mathrm{~g}, 4.09 \pm 0.04 \mathrm{~g} / 100 \mathrm{~g}$ 으로 나타나 대조군인 시판고추장에 비하여 복숭아 고추장의 fructose 함량이 높은 것을 알 수 있다. Maltose의 함량은 $\mathrm{CK}$ 군에서 $10.93 \pm 0.49 \mathrm{~g} / 100 \mathrm{~g}$ 의 함량을 보였고 $\mathrm{KHK}, \mathrm{CHK}, \mathrm{CWK}$, MK군은 $14.08 \pm 0.24 \mathrm{~g} / 100 \mathrm{~g}, 14.78 \pm 0.91 \mathrm{~g} / 100 \mathrm{~g}, 13.98 \pm$ $0.09 \mathrm{~g} / 100 \mathrm{~g}, 14.26 \pm 0.18 \mathrm{~g} / 100 \mathrm{~g}$ 으로 나타나 fructose 함량

Table 4. Free sugars content of Kochujang added with peach paste

\begin{tabular}{ccccc}
\hline Cultivar $^{1)}$ & $\begin{array}{c}\text { Fructose } \\
(\mathrm{g} / 100 \mathrm{~g})\end{array}$ & $\begin{array}{c}\text { Glucose } \\
(\mathrm{g} / 100 \mathrm{~g})\end{array}$ & $\begin{array}{c}\text { Sucrose } \\
(\mathrm{g} / 100 \mathrm{~g})\end{array}$ & $\begin{array}{c}\text { Maltose } \\
(\mathrm{g} / 100 \mathrm{~g})\end{array}$ \\
\hline KHK & $4.04 \pm 0.37^{2 \mathrm{bb})}$ & $8.70 \pm 0.05^{\mathrm{c}}$ & $0.00 \pm 0.00^{\mathrm{b}}$ & $14.08 \pm 0.24^{\mathrm{a}}$ \\
CHK & $3.79 \pm 0.07^{\mathrm{b}}$ & $8.09 \pm 0.22^{\mathrm{d}}$ & $0.00 \pm 0.00^{\mathrm{b}}$ & $14.78 \pm 0.91^{\mathrm{a}}$ \\
$\mathrm{CWK}$ & $4.55 \pm 0.05^{\mathrm{a}}$ & $9.33 \pm 0.24^{\mathrm{b}}$ & $0.00 \pm 0.00^{\mathrm{b}}$ & $13.98 \pm 0.09^{\mathrm{a}}$ \\
MK & $4.09 \pm 0.04^{\mathrm{b}}$ & $8.93 \pm 0.01^{\mathrm{c}}$ & $0.00 \pm 0.00^{\mathrm{b}}$ & $14.26 \pm 0.18^{\mathrm{a}}$ \\
CK & $0.89 \pm 0.01^{\mathrm{c}}$ & $14.47 \pm 0.05^{\mathrm{a}}$ & $0.13 \pm 0.04^{\mathrm{a}}$ & $10.93 \pm 0.49^{\mathrm{b}}$ \\
\hline
\end{tabular}

${ }^{11}$ KHK, Kanoiwa Hakuto Kochujang, CHK, Cheonhong Kochujang, CWK, Changhowon Hwangdo Kochujang, MK, mixed Kochujang, CK, commercial Kochujang.

${ }^{2)}$ Values are means $\pm S D$ of triplicate determinations.

${ }^{3)}$ Different superscripts within a column $(a-d)$ indicate significant differences $(p<0.05)$. 
의 결과와 유사하게 나타났다. 이는 복숭아의 과실에 함유 되어 있는 fructose와 조청에 함유되어 있는 maltose에서 기인된 것으로 사료된다. 반면 glucose의 함량은 대조군인 시판고추장에서 높은 결과를 나타냈다. Sucrose의 함량은 시판고추장에서 미량 검출되었지만, 복숭아 고추장에서는 검출이 되지 않았다.

\section{영양성분 및 무기원소 함량}

복숭아 품종별 고추장의 3대 영양소(탄수화물, 지방, 단 백질)의 함량을 분석한 결과는 Table 5 와 같다. 각각의 영양 소 함량을 분석한 결과 단백질은 $\mathrm{CK}$ 군에서 $6.01 \pm 0.04 \mathrm{~g} / 100$ $\mathrm{g}$ 의 함량을 보였고 $\mathrm{KHK}, \mathrm{CHK}, \mathrm{CWK}, \mathrm{MK}$ 군은 $4.32 \pm 0.03$ $\mathrm{g} / 100 \mathrm{~g}, 4.47 \pm 0.05 \mathrm{~g} / 100 \mathrm{~g}, 4.21 \pm 0.00 \mathrm{~g} / 100 \mathrm{~g}, 4.41 \pm 0.16$ $\mathrm{g} / 100 \mathrm{~g}$ 으로 실험군에 비하여 대조군이 높은 경향을 보였 다. 탄수화물의 함량은 $\mathrm{CK}$ 군에서 $52.19 \pm 0.20 \mathrm{~g} / 100 \mathrm{~g}$ 의 함 량을 보였고 $\mathrm{KHK}, \mathrm{CHK}, \mathrm{CWK}, \mathrm{MK}$ 군은 $49.51 \pm 0.04 \mathrm{~g} / 100$ $\mathrm{g}, 49.48 \pm 0.34 \mathrm{~g} / 100 \mathrm{~g}, 49.91 \pm 0.09 \mathrm{~g} / 100 \mathrm{~g}, 52.06 \pm 0.34 \mathrm{~g} / 100$ $\mathrm{g}$ 으로 단백질 함량의 결과와 유사하게 나타났다. 반면, 지 방 함량은 $\mathrm{CK}$ 군에서 $0.87 \pm 0.03 \mathrm{~g} / 100 \mathrm{~g}$ 의 함량을 보였고 $\mathrm{KHK}, \mathrm{CHK}, \mathrm{CWK}, \mathrm{MK}$ 군은 $1.05 \pm 0.12 \mathrm{~g} / 100 \mathrm{~g}, 1.10 \pm 0.06$ $\mathrm{g} / 100 \mathrm{~g}, 0.98 \pm 0.05 \mathrm{~g} / 100 \mathrm{~g}, 0.43 \pm 0.01 \mathrm{~g} / 100 \mathrm{~g}$ 으로 MK군을 제외한 실험군이 대조군에 비하여 높은 함량을 나타내었 다. 탄수화물과 지방의 함량은 $\mathrm{Oh}$ 등(28)의 브로콜리 잎 분말을 첨가하여 제조한 고추장의 이화학적 특성에 대한 연구와 유사한 결과를 얻었다. 반면, 단백질의 함량은 반대 의 경향을 보였다. 이는 브로콜리 잎 분말 첨가 고추장의제 조 시 단백질의 대부분을 차지하고 있는 메줏가루의 함량이 $11 \%$ 인 반면에 복숭아 고추장 제조 시 첨가하는 메줏가루의 함량은 $3 \%$ 이며, 이에 따라 메줏가루의 첨가 비율에 따른 결과라고 해석할 수 있다. 복숭아 품종별 고추장의 무기원 소 $(\mathrm{Na}, \mathrm{K}, \mathrm{Mg}, \mathrm{Ca})$ 함량을 분석한 결과는 Table 6와 같다. 나트륨 섭취량은 세계농업식량기구(FAO) 및 세계보건기 구(WHO)에서도 관심을 갖는 모니터링 지표이며, 한국인 의 나트륨 섭취량은 권고 수준 $(2,000 \mathrm{mg}$ 미만)의 2 배 이상 이다. 나트륨 과다 섭취로 인해 뇌졸중 및 심혈관계 질환의

Table 5. Nutrient contents of Kochujang added with peach paste

\begin{tabular}{cccc}
\hline Cultivar $^{1)}$ & $\begin{array}{c}\text { Protein } \\
(\mathrm{g} / 100 \mathrm{~g})\end{array}$ & $\begin{array}{c}\text { Total fat } \\
(\mathrm{g} / 100 \mathrm{~g})\end{array}$ & $\begin{array}{c}\text { Total carbohydrate } \\
(\mathrm{g} / 100 \mathrm{~g})\end{array}$ \\
\hline KHK & $4.32 \pm 0.03^{2) \mathrm{bc} 3)}$ & $1.05 \pm 0.12^{\mathrm{ab}}$ & $49.51 \pm 0.04^{\mathrm{b}}$ \\
CHK & $4.47 \pm 0.05^{\mathrm{b}}$ & $1.10 \pm 0.06^{\mathrm{a}}$ & $49.48 \pm 0.34^{\mathrm{b}}$ \\
CWK & $4.21 \pm 0.00^{\mathrm{c}}$ & $0.98 \pm 0.05^{\mathrm{ab}}$ & $49.91 \pm 0.09^{\mathrm{b}}$ \\
MK & $4.41 \pm 0.16^{\mathrm{bc}}$ & $0.43 \pm 0.01^{\mathrm{c}}$ & $52.06 \pm 0.34^{\mathrm{a}}$ \\
CK & $6.01 \pm 0.04^{\mathrm{a}}$ & $0.87 \pm 0.03^{\mathrm{b}}$ & $52.19 \pm 0.20^{\mathrm{a}}$ \\
\hline
\end{tabular}

${ }^{1} \mathrm{KHK}$, Kanoiwa Hakuto Kochujang, CHK, Cheonhong Kochujang, CWK, Changhowon Hwangdo Kochujang, MK, mixed Kochujang, CK, commercial Kochujang.

${ }^{2)}$ Values are means \pm SD of triplicate determinations.

${ }^{3}$ Different superscripts within a column (a-c) indicate significant differences $(\mathrm{p}<0.05)$.
발병률이 높아짐에 따라 심각한 사회문제로 인식되어 최근 전 세계적으로 나트륨 저 감화 정책을 실시하고 있다(29). 한편, 칼륨은 인체 내에서 결핍 시 부정맥, 위장질환, 신장질 환, 고혈압 등이 발병할 수 있는 필수 섭취원이다. 칼륨은 나트륨의 과잉 섭취로 인하여 발병되는 질환에 대하여 감소 시키는 기능이 있으며, 식품 섭취 시 나트륨과 칼륨의 비율 을 1:1에 가깝게 유지시키면 심혈관계 질환 및 고혈압 질환 에 도움을 줄 수 있다는 연구 결과가 있다(31). 본 연구에서

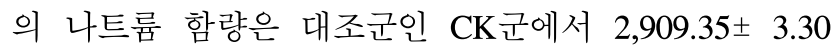
$\mathrm{mg} / 100 \mathrm{~g}$ 의 함량을 보였고 $\mathrm{KHK}, \mathrm{CHK}, \mathrm{CWK}, \mathrm{MK}$ 군은 $2,131.18 \pm 19.49 \mathrm{mg} / 100 \mathrm{~g}, 2,132.72 \pm 10.88 \mathrm{mg} / 100 \mathrm{~g}$, $2,136.78 \pm 1.26 \mathrm{mg} / 100 \mathrm{~g}, 2,107.56 \pm 11.74 \mathrm{mg} / 100 \mathrm{~g}$ 으로 실험 군에 비하여 대조군의 나트륨 함량이 높은 경향을 보였다. 반면, 칼륨 함량은 CK군에서 $806.88 \pm 9.84 \mathrm{mg} / 100 \mathrm{~g}$ 의 함량 을 보였고 $\mathrm{KHK}, \mathrm{CHK}, \mathrm{CWK}, \mathrm{MK}$ 군은 2,259.77 \pm 16.04 $\mathrm{mg} / 100 \mathrm{~g}, 2,266.88 \pm 24.30 \mathrm{mg} / 100 \mathrm{~g}, 2,311.98 \pm 22.75 \mathrm{mg} / 100$ $\mathrm{g}, 2,240.03 \pm 1.05 \mathrm{mg} / 100 \mathrm{~g}$ 으로 대조군에 비하여 실험군의 칼륨 함량이 높은 경향을 보였다. 이는 Dahl 등(31)의 연구 결과에 부합되는 결과로 복숭아 품종별 고추장의 나트륨이 저감되어 나트륨의 과잉 섭취를 줄일 수 있으며, 칼륨과 나트륨의 비가 $1: 1$ 에 가까운 결과로서 식품학적 의의가 있 다고 생각되었다. 한편, $\mathrm{Mg}$ 은 대조군인 $\mathrm{CK}$ 군에 비하여 복숭아 품종별 고추장의 함량이 낮은 결과를 보였으며, $\mathrm{Ca}$ 의 함량은 모두 유의적인 차이가 없었다. 이는 Kim 등(32)의 톳 발효 추출물을 이용한 고추장의 연구에서와 유사한 경향 을 나타내었다.

Table 6. Mineral contents of Kochujang added with peach paste

\begin{tabular}{ccccc}
\hline Cultivar $^{\mathrm{l}}{ }^{2}$ & $\begin{array}{c}\mathrm{Na} \\
(\mathrm{mg} / 100 \mathrm{~g})\end{array}$ & $\begin{array}{c}\mathrm{K} \\
(\mathrm{mg} / 100 \mathrm{~g})\end{array}$ & $\begin{array}{c}\mathrm{Mg} \\
(\mathrm{mg} / 100 \mathrm{~g})\end{array}$ & $\begin{array}{c}\mathrm{Ca} \\
(\mathrm{mg} / 100 \mathrm{~g})\end{array}$ \\
\hline KHK & $\left.2,131.18 \pm 19.49^{2) b 3}\right)$ & $2,259.77 \pm 16.04^{\mathrm{b}}$ & $64.13 \pm 1.17^{\mathrm{b}}$ & $18.43 \pm 0.78^{\mathrm{a}}$ \\
$\mathrm{CHK}$ & $2,132.72 \pm 10.88^{\mathrm{b}}$ & $2,266.88 \pm 24.30^{\mathrm{b}}$ & $65.82 \pm 0.35^{\mathrm{b}}$ & $20.24 \pm 2.26^{\mathrm{a}}$ \\
$\mathrm{CWK}$ & $2,136.78 \pm 1.26^{\mathrm{b}}$ & $2,311.98 \pm 22.75^{\mathrm{a}}$ & $64.67 \pm 0.03^{\mathrm{b}}$ & $16.39 \pm 3.78^{\mathrm{a}}$ \\
MK & $2,107.56 \pm 11.74^{\mathrm{b}}$ & $2,240.03 \pm 1.05^{\mathrm{b}}$ & $65.41 \pm 0.07^{\mathrm{b}}$ & $18.73 \pm 3.36^{\mathrm{a}}$ \\
$\mathrm{CK}$ & $2,909.35 \pm 3.30^{\mathrm{a}}$ & $806.88 \pm 9.84^{\mathrm{c}}$ & $141.14 \pm 0.86^{\mathrm{a}}$ & $15.47 \pm 1.61^{\mathrm{a}}$ \\
\hline
\end{tabular}

${ }^{1}$ KHK, Kanoiwa Hakuto Kochujang, CHK, Cheonhong Kochujang, CWK, Changhowon Hwangdo Kochujang, MK, mixed Kochujang, CK, commercial Kochujang.

${ }^{2)}$ Values are means $\pm S D$ of triplicate determinations.

${ }^{3)}$ Different superscripts within a column $(a-c)$ indicate significant differences $(p<0.05)$.

\section{총 페놀 및 플라보노이드 함량}

시판 고추장 및 복숭아 품종별 고추장을 $100 \%$ 에탄올과 증류수로 추출한 후 추출물내의 총 페놀 및 플라보노이드 함량을 측정한 결과는 Fig. 1에 나타내었다. 페놀 화합물은 식물계에 널리 분포되어 있는 phytochemical이며, 항산화 효과 및 항암, 항염증 효과가 있는 것으로 보고되었다(33). 플라보노이드는 식물체에 존재하는 색소로서 페놀에 속하 는 성분이며, 항균 및 항알러지에 대한 효과가 있다는 연구 
가 보고되어 있다(34). 페놀의 함량은 증류수 추출물에서 유의적인 차이가 없었지만, 에탄올 추출물에서 대조군인 $\mathrm{CK}$ 군은 $4.45 \pm 0.67 \mathrm{mg} \mathrm{GAE} / \mathrm{g}$ 의 함량을 나타내었고, $\mathrm{KHK}$, CHK, CWK, MK군은 $5.12 \pm 0.70 \mathrm{mg} \mathrm{GAE} / \mathrm{g}, 5.99 \pm 0.35 \mathrm{mg}$ $\mathrm{GAE} / \mathrm{g}, 4.83 \pm 0.65 \mathrm{mg} \mathrm{GAE} / \mathrm{g}$ 및 $5.74 \pm 0.44 \mathrm{mg} \mathrm{GAE} / \mathrm{g}$ 의 페놀 함량을 나타내었다. 반면, 플라보노이드의 함량은 증 류수 추출물에서 유의적인 차이가 없었지만, 에탄올 추출 물에서 $\mathrm{CK}$ 군은 $2.78 \pm 0.65 \mathrm{mg} \mathrm{CE} / \mathrm{g}$ 의 함량을 보였고, $\mathrm{KHK}$, $\mathrm{CHK}, \mathrm{CWK}, \mathrm{MK}$ 군은 $2.42 \pm 0.35 \mathrm{mg} \mathrm{CE} / \mathrm{g}, 2.61 \pm 0.07 \mathrm{mg}$ $\mathrm{CE} / \mathrm{g}, 2.07 \pm 0.25 \mathrm{mg} \mathrm{CE} / \mathrm{g}$ 및 $2.05 \pm 0.06 \mathrm{mg} \mathrm{CE} / \mathrm{g}$ 의 플라보노 이드 함량을 나타내어, 페놀 함량과 플라보노이드의 함량 이 대비되는 결과를 나타내었다.

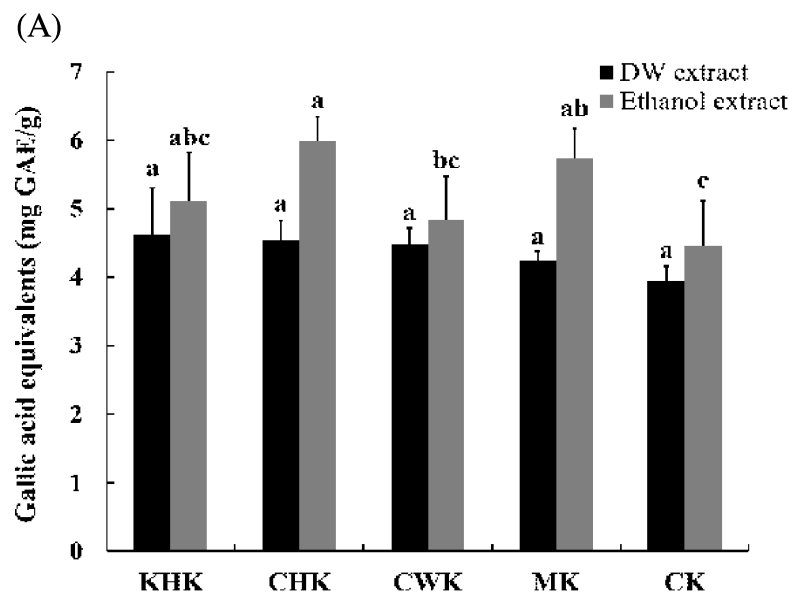

(B)

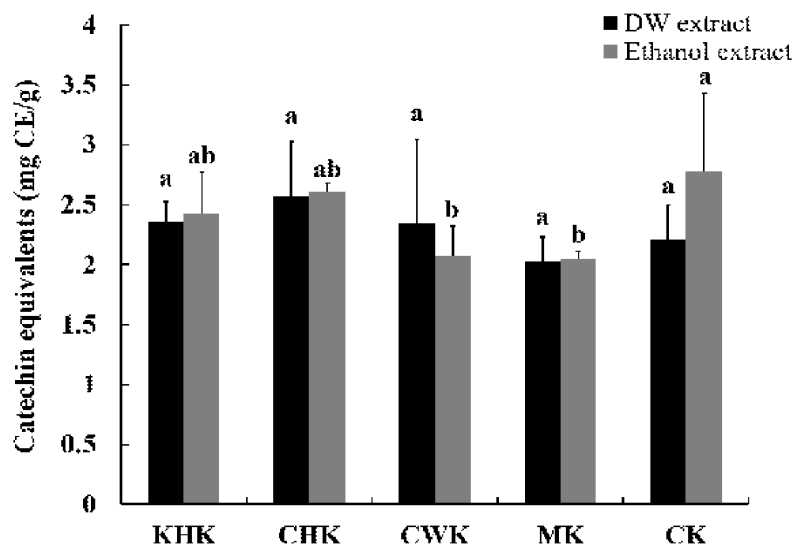

Fig. 1. Total (A) phenols and (B) flavonoids content of Kochujang added with peach paste.

KHK, Kanoiwa Hakuto Kochujang, CHK, Cheonhong Kochujang, CWK, Changhowon Hwangdo Kochujang, MK, mixed Kochujang, CK, commercial Kochujang.

Values are means \pm SD of triplicate determinations. Different superscripts within a column $(a-b)$ indicate significant differences $(p<0.05)$.

\section{$\mathrm{DPPH}$ 및 ABTS 라디컬 소거 활성}

시판 고추장 및 복숭아 품종별 고추장을 $100 \%$ 에탄올과 증류수로 추출한 후 추출물의 DPPH 및 ABTS 라디컬 소거 활성 결과는 Fig. 2에 나타내었다. DPPH 라디컬 소거 활성
은 에탄올 추출물에서 유의적인 차이를 보이지 않았지만, 증류수 추출물에서 $\mathrm{CK}$ 군은 $7.71 \pm 1.26 \mathrm{mg} / \mathrm{mL}$ 의 $50 \%$ 저해 농도의 결과를 보였고, $\mathrm{KHK}, \mathrm{CHK}, \mathrm{CWK}, \mathrm{MK}$ 군은 $5.57 \pm 0.61 \mathrm{mg} / \mathrm{mL}, 5.37 \pm 1.23 \mathrm{mg} / \mathrm{mL}, 6.53 \pm 0.50 \mathrm{mg} / \mathrm{mL}$ 및 $5.73 \pm 0.56 \mathrm{mg} / \mathrm{mL}$ 의 $50 \%$ 저해 농도를 보여 시판 고추장에 비하여 복숭아 고추장의 라디컬 소거능이 더 높은 결과를 보였다. ABTS 라디컬 소거 활성에서는 DPPH 라디컬 소거 활성의 결과와 마찬가지로 에탄올 추출물에서 유의적인 차이를 보이지 않았지만, 증류수 추출물에서 $\mathrm{CK}$ 군은 $1.96 \pm 0.10 \mathrm{mg} / \mathrm{mL}$ 의 $50 \%$ 저해 농도의 결과를 보였고, $\mathrm{KHK}$, CHK, CWK, MK군은 $1.89 \pm 0.10 \mathrm{mg} / \mathrm{mL}, 1.63 \pm 0.10 \mathrm{mg} / \mathrm{mL}$, $2.30 \pm 0.40 \mathrm{mg} / \mathrm{mL}$ 및 $1.95 \pm 0.16 \mathrm{mg} / \mathrm{mL}$ 의 $50 \%$ 저해 농도를 보였다. 특히 $\mathrm{CHK}$ 군은 증류수 추출물에서 $\mathrm{DPPH}$ 및 $\mathrm{ABTS}$ 라디컬 소거능이 다른 고추장에 비하여 우수하다는 결과를 보였다.

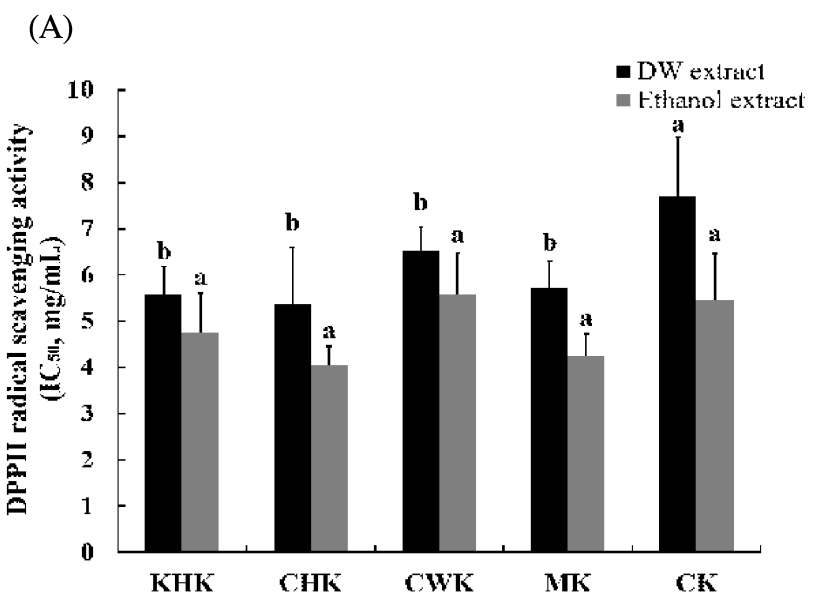

(B)

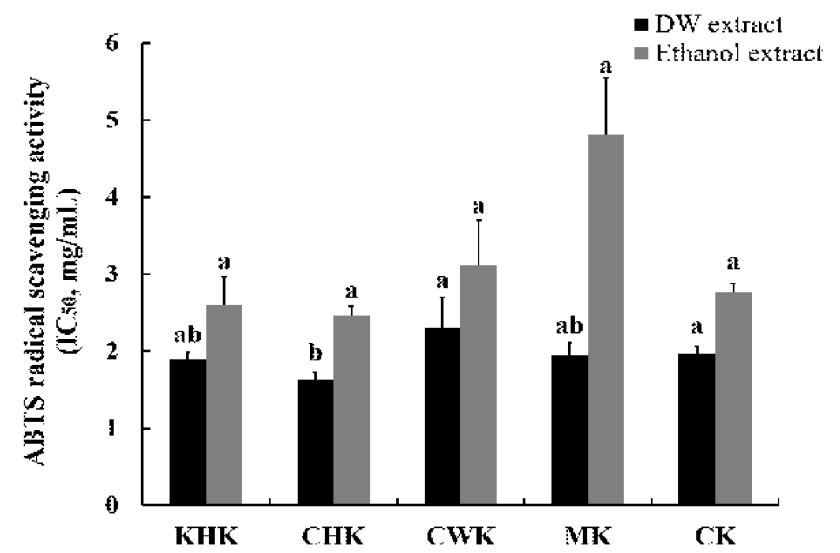

Fig. 2. (A) DPPH and (B) ABTS radicals scavenging activities of Kochujang added with peach paste.

KHK, Kanoiwa Hakuto Kochujang, CHK, Cheonhong Kochujang, CWK, Changhowon Hwangdo Kochujang, MK, mixed Kochujang, CK, commercial Kochujang.

Values are means $\mathrm{SD}$ of triplicate determinations. Different superscripts within a column $(\mathrm{a}-\mathrm{b})$ indicate significant differences $(\mathrm{p}<0.05)$. 


\section{요 약}

본 연구는 저장성이 낮아 폐기되는 복숭아를 활용하여 고추장을 담금하여 품질 특성을 조사하였다. $\mathrm{pH}$, 당도, 염 도, 환원당, 회분 및 열량은 시판 고추장에 비하여 복숭아 고추장이 낮은 경향을 보였으나, 산도 및 수분은 복숭아 과육의 높은 유기산 및 수분의 함량으로 다소 높은 결과를 얻었다. 유리당 함량의 비교에서 glucose는 시판 고추장이 복숭아 고추장에 비하여 높은 함량을 보였지만, fructose와 maltose는 복숭아 고추장에서 높은 함량을 보였다. 3 대 영양 소의 함량은 단백질과 탄수화물에서 시판 고추장의 함량이 높았으며, 지방은 복숭아 고추장의 함량이 높았다. 무기원 소의 함량은 나트륨과 마그네슘에서 시판 고추장이 높게 측정되었으며, 칼륨 함량은 복숭아 고추장에서 높은 결과 를 보였다. 페놀 및 플라보노이드의 함량을 비교한 결과, 증류수 추출물에서는 유의적인 차이가 없었지만, 페놀 함 량에서 복숭아 고추장의 에탄올 추출물이 시판 고추장의 추출물 보다 더 높은 결과를 가져왔다. 또한, DPPH 및 $\mathrm{ABTS}$ 라디컬 소거 활성을 비교한 결과 에탄올 추출물에서 는 유의적인 차이가 없었지만, 증류수 추출물에서 $\mathrm{DPPH}$ 라디컬 소거 활성이 더 높게 나타났다. 이와 같이 복숭아 품종별 페이스트를 이용하여 제조한 고추장의 이화학적 품질 특성을 조사한 결과, 대부분의 품종에서 시판고추장 에 비해 품질이 높게 나타나 상품화의 가능성이 있는 것으 로 기대된다. 향후 담금 조건, 관능적 특성, 숙성 기간 및 유통 안전성에 관한 연구가 요망되었다.

\section{감사의 글}

본 연구는 2016년 농촌진흥청의 재원으로 경상북도 지원 을 통해 수행중인 '복숭아를 이용한 저염고추장 개발(과제 번호: PJ012004)'의 연구비 지원으로 진행되었으며, 이에 감사드립니다.

\section{References}

1. Shin DH, Ahn EY, Kim YS, Oh JY (2000) Fermentation characteristics of Kochujang containing horseradish or mustard. Korean J Food Sci Technol, 32, 1350-1357

2. Cho HO, Park SA, Kim JG (1981) Effect of traditional and improved Kochujang koji on the quality improvement of traditional Kochujang. Korean J Food Sci Technol, 13, 319-327

3. Lee SM, Lim IJ, Yoo BS (2003) Effect of mixing ratio on rheological properties of Kochujang. Korean J Food
Sci Technol, 35, 44-51

4. Hwang SJ, Kim JY, Eun JB (2011) Physical characteristics and changes in functional components of Gochujang with different amounts of sweet persimmon powder. J Korean Soc Food Sci Nutr, 40, 1668-1674

5. Choi SK, Shin KE, Lee MS, Kim SH, Choi EH (2010) A study on the quality characteristics and utilization of jujube Kochujang. Korean J Culinary Res, 16, 264-276

6. Kim OS, Sung JM, Ryu HS (2012) Antioxidative activity and quality characteristics of Kochujang amended with different ratios of Deodeok (Condonopsis lanceolata) root powder. J East Asian Soc Dietary Life, 22, 667-676

7. Lee MS, Park ML, Jung HA, Choi SK (2011) Quality characteristics of Gochujang dressing containing various amounts of Maesil (Prunus mune) concentrate. J East Asian Soc Dietary Life, 21, 38-45

8. Kim SH (2016) Study on nutritional property and use potential of Gochujang using Gongju chestnuts. J Nutr Health, 49, 395-399

9. Ryu HM, Jeon DK, Kim SA, Chung HJ (2013) Antioxidant and quality characteristics of mungbean starch gel added with peach seed powder. Korean J Food Preserv, 20, 372-378

10. Lee DS, Woo SK, Yang CB (1972) Studies on the chemical composition of major fruits in Korea: On non-volatile organic acid and sugar contents of apricot (Maesi), peach, grape, apple and pear and its seasonal variation. Korean J Food Sci Technol, 4, 134-139

11. Lee KH, Lee YC (1995) Flavor quality of aroma fractions recovered from peach pulp. Korean J Food Sci Technol, 27, 921-927

12. Whitelock DP, Brusewitz GH, Smith MW, Zhang X (1994) Humidity and airflow during storage affect peach quality. HortScience, 29, 798-801

13. Kim BS, Kim MJ, Choi JH (2003) Effects of precooling treatments on the quality of peaches (Mibaek). Korean J Food Sci Technol, 35, 1233-1236

14. Nah HS, Bae RN, Lee SK (2012) Effect of nitrous oxide (N2O) treatment on quality of peach (Prunus persica) postharvest. Korean J Hort Sci Technol, 30, 42-49

15. Lee MS, Park ML, Jung HA, Choi SK (2011) Quality characteristics of Gochujang dressing containing various amounts of Maesil (Prunus mune) concentrate. J East Asian Soc Diet Life, 21, 38-45

16. Kang MK, Song KB (2006) Quality characteristics of Kochujang with the addition of skipjack cooking broth as protein source. Korean J Food Preserv, 13, 457-464 
17. Korean Food Standards Codex. http://fse.foodnara. go.krresidue/RS/jsp/ menu_02_01_01.jsp (accessed December 2013)

18. AOAC (1990) Official Methods of Analysis. $15^{\text {th }}$ ed, Association of Official Analytical Chemists, Washington DC, USA, p 777-788

19. Folin O, Denis W (1912) On phosphotungsticphosphomolybdic compounds as color reagents. J Biol Chem, 12, 239-243

20. Zhishen J, Mengcheng T, Jianming W (1999) The determination of flavonoid contents in mulberry and their scavenging effects on superoxide radicals. Food Chem, 64, 555-559

21. Blois MS (1958) Antioxidant determinations by the use of a stable free radical. Nature, 181, 1199-1200

22. Re R, Pellegrini N, Proteggente A, Pannala A, Yang M, Rice-Evans C (1999) Antioxidant activity applying an improved ABTS radical cation decolorization assay. Free Radical Biol Med, 26, 1231-1237

23. Lee HY, Youn KS (2012) Quality characteristics of cold-air and infrared-dried peaches. Korean J Food Preserv, 19, 485-491

24. Youn KJ, Kim JY, Yeo HR, Jun MR (2011) Improving the functional quality of Kochujang added with red ginseng and fermented wild herbal extract. J Korean Soc Food Sci Nutr, 40, 1675-1679

25. Lee MJ, Lee JH (2006) Quality characteristics of Kochujang prepared with Maesil (Prunus mume) extract during aging. J Korean Soc Food Sci Nutr, 35, 622-628
26. Chapman GW, Horvert RJ, Forbus WR (1991) Physical and chemical changes during the maturation of peaches (cv. majestic). J Agr Food Chem, 39, 867-870

27. Moriguchi T, Sanada T, Yamaki S (1991) Properties of acid invertase purified from peach fruits. Phytochemistry, 30, 95-97

28. Oh YS, Baek JW, Park KY, Hwang JH, Lim SB (2013) Physicochemical and functional properties of Kochujang with broccoli leaf powder. J Korean Soc Food Sci Nutr, 42, 675-681

29. Kweon SH (2013) Intakes of calcium and dairy products in Korean national health and nutrition examination survey. Public Health Wkly Rep, 6, 821-827

30. Dahl LK, Leitl G, Heine M (1972) Influence of dietary potassium and sodium/potassium molar ratios on the development of salt hypertension. J Exp Med, 136, 318-330

31. Kim JH, Song HS, Yang JY (2012) Nutritional characteristics of Kochujang added with fermented extracts of Hizikia fusiforme. J Food Hyg Saf, 27, 473-478

32. Lu Y, Foo LY (2000) Antioxidant and radical scavenging activities of polyphenols from apple pomace. Food Chem, $68,81-85$

33. Lee JH, Park AR, Choi DW, Kim JD, Kim JC, Ahn JH, Lee HY, Choe M, Choi KP, Shin IC, Park HJ (2011) Analysis of chemical compositions and electron-donating ability of 4 Korean wild Sannamuls. Korean J Medicinal Crop Sci, 19, 111-116 